\title{
OPTIMALISASI HARGA KOMODITI AGROFORESTRI UNTUK MENINGKATKAN PENDAPATAN PETANI
}

\author{
Rudi Hilmanto \\ Jurusan Manajemen Hutan Fakultas Pertanian Universitas Lampung \\ e-mail: rudihilmanto@gmail.comTelp.08127287225
}

\section{Abstract}

Farmer often undergo of constraint in determining optimal price so that the farmer often undergo of loss, it is because the price of the commodity sold is less than the cost of production in the management of agroforestry systems. Determination Optimalization price of commodity agroforestry expected able to improve income of farmer agroforestry maximally. Objectives of this Research is to analyze the optimization of agrocommodity prices to increase farmers' income. This research used Rudihilmanto Pricing method. Result of this research points out proportion plants: coffee (98.30\%), clove $(0.45 \%)$, melinjo $(0.23 \%)$, and petai $(1.02 \%)$ in farmers' fields have optimal price $\geq$ real price so that this condition has risks and disadvantages for farmers now, but if the proportion is changed as coffee (31.77\%), clove (28.79\%), melinjo (19.06\%), petai (20.37\%), therefore optimal price is lower than the real price and it is possible to provide the maximum gain to the farmers of Rp.122,056,970.00 per annum in one hectare.

Petani sering mengalami kendala dalam menentukan harga optimal sehingga petani sering mengalami kerugian, hal ini karena harga komoditi yang dipasarkan lebih kecil daripada biaya produksi dalam pengelolaan sistem agroforestri. Penentuan optimalisasi harga pada komoditi agroforestri diharapkan mampu meningkatkan pendapatan petani pengelola agroforestri secara maksimal. Tujuan penelitian ini adalah untuk menganalisis optimalisasi harga komoditi agroforestri untuk meningkatkan pendapatan petani. Penelitian ini menggunakan metode Harga Rudihilmanto. Hasil penelitian menunjukkan proporsi tanaman kopi $(98,30 \%)$, cengkeh $(0,45 \%)$, melinjo $(0,23 \%)$, dan petai $(1,02 \%)$ di lahan petani memiliki harga optimal $\geq$ harga riil sehingga kondisi ini memiliki risiko dan kerugian bagi petani, tetapi apabila proporsi diubah menjadi tanaman kopi $(31,77 \%)$, cengkeh $(28,79 \%)$, melinjo $(19,06 \%)$, petai $(20,37 \%)$ maka harga optimal $\leq$ harga riil dan dimungkinkan mampu memberikan keuntungan yang maksimal bagi petani sebesar Rp.122.056.970,00 tiap tahun dalam satu hektar.

\section{Keywords}

Price ,Optimal, Income, Maximal, Agroforestry

Harga,Optimal, Pendapatan, Maksimal, Agroforestri

\section{PENDAHULUAN}

Perlindungan lahan pertanian dan kehutanan perlu dilakukan untuk mencegah alih fungsi lahan. Menurut Fauzi \& Rachmawati (2005) hingga tahun 2006 tercatat 9.906 hektar daerah budidaya pertanian, yaitu: berupa perkebunan karet, pisang, kebun campuran, dan pertanian lahan kering yang dikonversi menjadi lahan pertambangan, hal ini berkaitan dengan kebijaksanaan makro ekonomi yang membuat lahan pertanian dan kehutanan dinilai rendah (under valued) (Gunawan, 2010).

Salah satu faktor secara makro ekonomi lahan pertanian dinilai rendah, adalah: karakteristik komoditi pertanian dalam struktur pasar yang bersifat homogen dan massal. Sifat homogen menunjukkan bahwa produsen tidak bisa mengindikasi sumber-sumber penawaran yang disubstitusi secara sempurna oleh produsen lainnya. Sifat massal memberikan indikasi bahwa jumlah komoditi pertanian yang dihasilkan seorang produsen dianggap sangat kecil dibandingkan jumlah komoditi total yang dipasarkan, sehingga produsen pertanian secara individu tidak dapat mempengaruhi harga yang berlaku di pasar dan bertindak hanya sebagai penerima harga (price taker).

Usaha perlindungan lahan secara ekonomi, ekologi, dan sosial saat ini diwujudkan dengan sistem agroforestri (Hilmanto, 2010), tetapi pada kenyataannya pengelolaan sistem agroforestri saat ini dirasakan kurang optimal 
karena rendahnya pendapatan petani yang disebabkan ketidaksesuaian antara biaya produksi dengan harga komoditi agroforestri yang dijual ke pasar (Wijatnika, 2009), sedangkan harga komoditi agroforestri secara umum ditetapkan oleh petani lokal berdasarkan biaya produksi (Cost-Based Pricing).

Hal ini karena adanya fluktuasi harga komoditi yang bisa terjadi karena harga komoditi pertanian dan kehutanan menurun pada musim panen raya, sehingga petani sering mengalami kerugian (Hilmanto dan Rahayu 2011). Harga jual yang rendah membuat petani berhadapan dengan kondisi pilihan yang sulit, yaitu antara menjual komoditi tetapi bisa menjadi rugi karena harus mengeluarkan biaya produksi dari komoditi yang dipanen, tetapi petani harus memiliki uang tunai untuk modal usaha tani pada musim tanam selanjutnya serta memenuhi kebutuhan sehari-hari (Hilmanto dan Rahayu, 2011). Pada saat tertentu harga komoditi bisa naik, karena barang yang tersedia di pasar menjadi sedikit (Hilmanto dan Rahayu, 2011).

Pengelolaan harga dan pemasaran diharapkan mampu meningkatkan pendapatan yang optimal dari usaha tani sehingga pengelolaan usaha tani melalui sistem agroforestri mampu lebih ditingkatkan dan dikembangkan, sehingga tujuan penelitian ini, adalah menganalisis optimalisasi harga komoditi agroforestri untuk meningkatkan pendapatan petani.

\section{KAJIAN TEORI}

Pasar merupakan muara dari sistem agroforestri, sehingga diperlukan pemahaman mengenai pengelolaan sistem pemasaran. Pengelolaan sistem pemasaran mempunyai tujuan, yaitu: mendirikan, mengembangkan, mempertahankan dan meregenerasikan sistem agroforestri. Indikator pengelolaan sistem pemasaran yang baik dapat diamati dari konsep bauran pasar (marketing mix) (Purwanto et al., 2009).

Konsep bauran pemasaran (marketing mix) mempunyai peranan sangat penting dalam strategi pemasaran. Menurut Kotler (dalam Trison, 2008), bauran pemasaran (marketing $m i x)$, adalah: seperangkat alat pemasaran yang digunakan perusahan untuk terus-menerus mencapai tujuan pemasarannya di pasar sasaran. Alat-alat tersebut dapat digunakan untuk menyusun strategi jangka panjang dan jangka pendek.

Model-model dan metode bauran pemasaran yang sudah berkembang saat ini, adalah: pengalokasian bobot pada komponen marketing mix dengan metode ANP (Analytic Network Process) (Sadic, 2010), model optimasi marketing mix dengan menentukan berapa banyak alokasi biaya pada pemasangan iklan untuk meningkatkan pemasaran dengan beberapa produk dengan algoritma dan regresi non-linear (Thinkalytics, 2008). Konsep marketing mix merupakan kombinasi $4 \mathrm{P}$, yaitu: (1) Product (barang atau jasa); (2) Price (harga); (3) Promotion (promosi); dan (4) Place (tempat) atau distribusi, sehingga tujuan penelitian ini, adalah: mengetahui harga optimal pemasaran untuk memaksimalkan pendapatan petani agroforestri dengan menentukan alokasi biaya produksi, promosi, dan distribusi komoditi agroforestri.

\section{METODE}

Penelitian ini menggunakan 30 responden, di Dusun Lubuk Baka. Penelitian ini menggunakan metode "Harga Rudihilmanto" (Hilmanto, 2010). Metode ini dalam salah satu aplikasinya berfungsi menentukan harga optimal untuk memaksimalkan pendapatan petani agroforestri dengan cara memasukan biaya produksi komoditi dan biaya lainnya ke dalam kendala-kendala menggunakan fungsi objektif dalam linear programing (Hilmanto, 2010; Hilmanto, 2011). Metode ini untuk mempermudahnya menggunakan bantuan program komputer (Hilmanto, 2010, Hilmanto 2011).

Komoditi-komoditi sebagai objek penelitian ini adalah: kopi, cengkeh, melinjo, dan petai yang ditanam dalam satu lahan sebagai teknik pengelolaan lahan dengan sistem agroforestri. Sehingga rumus-rumus yang digunakan dalam penelitian ini adalah:

1. Rumus-rumus yang digunakan pada metode ini adalah (Hilmanto, 2010, Hilmanto, 2011):

a. Titik impas harga (BEP Harga)(Bernard T, et.al,, 2008)

$=$ Total biaya/Total produksi

b. Pendapatan maksimal kopi: 
$=$ (Harga optimal kopi) $\times$ (Jumlah produksi kopi)

c. Pendapatan maksimal cengkeh:

$=$ (Harga optimal cengkeh) $\times$ (Jumlah produksi cengkeh)

d. Pendapatan maksimal melinjo:

$=$ (Harga optimal melinjo) x (Jumlah produksi melinjo)

e. Pendapatan maksimal petai:

$=$ (Harga optimal petai) $\times$ (Jumlah produksi petai)

f. Pendapatan total maksimal komoditi agroforestri:

$=$ (Pendapatan maksimal kopi + cengkeh + melinjo + petai)

2. Fungsi objektif dalam linear programing pada penelitian ini, yaitu (Hilmanto, 2010, Hilmanto, 2011):

a. Harga optimal, yang didasarkan dari biaya produksi, promosi, dan distribusi.

b. Biaya produksi optimal, promosi optimal, dan distribusi optimal.

c. Pendapatan maksimum komoditi agroforestri pada penelitian ini (Z) adalah:

$Z=870$ kopi +4 cengkeh +2 melinjo +9 petai

\section{HASIL}

Hasil penelitian menunjukkan bahwa data komponen biaya produksi sistem agroforestri pada tanaman kopi, cengkeh, melinjo, dan petai adalah: sewa lahan, tenaga pembuatan lubang angin, pupuk kandang, tenaga pemupukan, tenaga pemangkas, tenaga penyiangan, tenaga panen, peralatan, biaya tidak terduga, bunga riil, promosi, dan distribusi. Hal ini dapat dilihat pada Tabel 1.

Total biaya produksi rata-rata untuk pengelolaan sistem agroforestri tanaman kopi, cengkeh, melinjo, dan petai sebesar Rp.12.983.930,-. Total produksi rata-rata dalam satu tahun tanaman kopi dan cengkeh sebesar $591 \mathrm{~kg} /$ tahun $/ \mathrm{ha}$, sehingga titik impas (BEP) harga sebesar Rp.21.952,- $\mathrm{kg} / \mathrm{th} / \mathrm{ha}$. Komponen-komponen biaya produksi pada usaha tani dengan sistem agroforestri untuk tanaman kopi, cengkeh, melinjo, dan petai pada satu lahan seluas satu hektar.
Tabel 1. Rata-rata Biaya Produksi Komoditi Agroforestri Dalam Tiap Hektar (ha)

\begin{tabular}{lcc}
\hline \multicolumn{1}{c}{ Komponen } & \multicolumn{1}{c}{ Biaya } \\
\hline Sewa lahan & $\mathrm{Rp} 3.000 .000,00$ \\
Tenaga pembuatan lubang angin & & \\
(20 HKP) & $\mathrm{Rp} 200.000,00$ \\
Pupuk kandang & $\mathrm{Rp} 2.000 .000,00$ \\
Tenaga pemupukan (20 HK) & $\mathrm{Rp} 200.000,00$ \\
Tenaga Pemangkas (60 HKW) & $\mathrm{Rp} 500.000,00$ \\
Tenaga Penyiangan (60 HKW) & $\mathrm{Rp} 500.000,00$ \\
Tenaga Panen (120 HKW+30 & \\
HKP) & $\mathrm{Rp} 1.200 .000,00$ \\
Peralatan & $\mathrm{Rp} 1.000 .000,00$ \\
Bunga ril (selisih antara suku & \\
bunga nominal dengan laju inflasi & \\
(6.78\%) & $\mathrm{Rp} 633.930,00$ \\
Biaya tidak terduga (10\%) & $\mathrm{Rp} 850.000,00$ \\
Tenaga pengendali hama (90 & $\mathrm{Rp} 900.000,00$ \\
HKP) & $\mathrm{Rp} 1.000 .000,00$ \\
Promosi & $\mathrm{Rp} 1.000 .000,00$ \\
Distribusi & $\mathrm{Rp} 12.983 .930,00$ \\
\hline Total Biaya & $591 \mathrm{~kg} / \mathrm{th} / \mathrm{ha}$ \\
Total Produksi & $\mathrm{Rp} \mathrm{21.952,00}$ \\
& $\mathrm{kg} / \mathrm{th} / \mathrm{ha}$ \\
\hline Titik Impas (BEP) harga &
\end{tabular}

Data primer (2012)

Ket: (HKP) hari kerja pria selama 8 jam

(HKW) hari kerja wanita selama 6 jam

\section{Optimalisasi Harga Komoditi}

Kendala-kendala dalam penentuan harga optimal tiap komoditi dijabarkan dengan fungsi objektif dalam linear programming, yaitu penentuan harga optimal ditentukan di atas titik impas (Break Event Point-BEP) harga, penentuan harga di atas titik impas dengan tujuan untuk mencapai pendapatan maksimal dari pengelolaan sistem agroforestri. Fungsi objektif dari penentuan harga optimal, yaitu:

- Harga optimal kopi $\geq$ titik impas (BEP) harga = Harga optimal kopi $\geq$ Rp.21.952,00

- Harga optimal cengkeh $\geq$ titik impas (BEP) harga = Harga optimal cengkeh $\geq$ Rp.21.952,00

- Harga optimal melinjo $\geq$ titik impas (BEP) harga $=$ Harga optimal melinjo $\geq$ Rp.21.952,00

- Harga optimal petai $\geq$ titik impas (BEP) harga $=$ Harga optimal petai $\geq$ Rp.21.952,00

Hasil kendala-kendala dalam penentuan harga optimal tiap komoditi dapat dilihat pada Tabel 2. 
Tabel 2. Harga Optimal Tiap Komoditi

Agroforestri

\begin{tabular}{lcclr}
\hline Nama & $\begin{array}{c}\text { Titik impas } \\
\text { (BEP) harga } \\
(\mathbf{R p})\end{array}$ & $\begin{array}{c}\text { Harga } \\
\text { Optimal } \\
(\mathbf{R p})\end{array}$ & $\begin{array}{c}\text { Status } \\
\text { selisih }\end{array}$ & $\begin{array}{c}\text { Selisih } \\
\text { (Rp) }\end{array}$ \\
\hline Kopi & 21.952 & 21.971 & Not Binding & 19 \\
Cengkeh & 21.952 & 22.102 & Not Binding & 150 \\
Melinjo & 21.952 & 21.952 & Binding & - \\
Petai & 21.952 & 21.952 & Binding & - \\
\hline
\end{tabular}

Harga optimal kopi dari pengolahan data menggunakan program komputer terlihat sebesar Rp.21.971,00. Harga optimal kopi sesuai dengan nilai yang diharapkan, yaitu sebesar Rp21.952,00 atau lebih besar daripada nilai titik impas (BEP). Harga optimal cengkeh sebesar Rp22.102,00. Harga optimal cengkeh sesuai dengan nilai yang diharapkan, yaitu sebesar Rp21.952,00 atau lebih besar daripada titik impas (BEP). Harga optimal melinjo dan petai sesuai dengan nilai yang diharapkan, yaitu sebesar Rp21.952,00 atau sama dengan titik impas (BEP). sebesar 29,04 kg/tahun. Jumlah tanaman melinjo sebanyak 2 (dua) tanaman dengan jarak tanam $6 \mathrm{~m} \times 6 \mathrm{~m}$ yang sedang berproduksi sebesar $28,14 \mathrm{~kg} /$ tahun. Jumlah tanaman petai sebanyak 9 (sembilan) tanaman dengan jarak tanam $6 \mathrm{~m} \times 6 \mathrm{~m}$ yang sedang berproduksi sebesar 108 kg/tahun. Areal lahan yang dikelola seluas 1 hektar (ha). Secara rinci variabel kendala-kendala dijabarkan dengan fungsi objektif dalam linear programing, yaitu:

- Sewa tanah: alokasi sewa tanah di dasarkan perbandingan jumlah tanaman antara tanaman kopi, cengkeh, melinjo, dan petai, fungsi objektif, yaitu:

133,40 harga optimal kopi $+0,61$ harga optimal cengkeh $+0,31$ harga optimal melinjo $+1,38$ harga optimal petai $\leq$ $3.000 .000,00$

- Tenaga kerja: alokasi tenaga kerja di dasarkan perbandingan jumlah tanaman antara tanaman kopi, cengkeh, melinjo, dan petai, fungsi objektif, yaitu:

Tabel 3. Nilai Optimal Penentuan Alokasi Komponen Komoditi Agroforestri

\begin{tabular}{|c|c|c|c|c|}
\hline Komponen & $\begin{array}{l}\begin{array}{l}\text { Nilai yang } \\
\text { diharapkan }\end{array} \\
\end{array}$ & Nilai optimal & $\begin{array}{l}\text { Status } \\
\text { selisih }\end{array}$ & Selisih \\
\hline Sewa tanah & Rp3.000.000,00 & Rp2.981.460,00 & Not Binding & Rp18.540,00 \\
\hline Tenaga Kerja & Rp3.500.000,00 & Rp3.499.974,00 & Not Binding & 26,00 \\
\hline Pupuk Kandang & Rp2.000.000,00 & Rp1.944.430,00 & Not Binding & Rp55.570,00 \\
\hline Peralatan & Rp1.000.000,00 & Rp 993.820,00 & Not Binding & Rp 6.180,00 \\
\hline Bunga riil & $\operatorname{Rp} \quad 633.930,00$ & Rp $626.539,00$ & Not Binding & $\operatorname{Rp} 7.391,00$ \\
\hline Biaya tidak terduga & Rp $850.000,00$ & Rp $842.586,00$ & Not Binding & Rp 7.414,00 \\
\hline Promosi & Rp1.000.000,00 & Rp1.000.000,00 & Binding & $\mathrm{Rp}$ \\
\hline Distribusi & Rp1.000.000,00 & Rp1.000.000,00 & Binding & $\mathrm{Rp}$ \\
\hline Jumlah & Rp12.983.930,00 & Rp12.888.809,00 & & Rp95.121,00 \\
\hline
\end{tabular}

Sumber: data diolah (2011)

\section{Optimalisasi Biaya Produksi, Promosi, dan Distribusi}

Variabel kendala-kendala dalam penentuan optimal biaya produksi pada komponen tiap komoditi agroforestri didasarkan jumlah ratarata tanaman dan jumlah rata-rata produksi tanaman pada responden. Jumlah tanaman kopi sebanyak 870 tanaman dengan jarak tanam $3 \mathrm{~m} \times 3 \mathrm{~m}$ yang sedang berproduksi sebesar $426,30 \mathrm{~kg} /$ tahun. Jumlah tanaman cengkeh sebanyak 4 (empat) tanaman dengan jarak tanam $6 \mathrm{~m} \times 6 \mathrm{~m}$ yang sedang berproduksi
156,60 harga optimal kopi $+0,72$ harga optimal cengkeh $+0,36$ harga optimal melinjo $+1,62$ harga optimal petai $\leq$ $3.500 .000,00$

- Pupuk: alokasi penggunaan pupuk di dasarkan pada jumlah tanaman yang ada antara tanaman kopi, cengkeh, melinjo, dan petai, fungsi objektif, yaitu:

87 harga optimal kopi $+0,40$ harga optimal cengkeh $+0,20$ harga optimal melinjo $+0,90$ harga optimal petai $\leq 2.000 .000,00$

- Peralatan: alokasi peralatan di dasarkan pada jumlah tanaman yang ada antara 
tanaman kopi, cengkeh, melinjo, dan petai, fungsi objektif, yaitu:

44,47 harga optimal kopi $+0,20$ harga optimal cengkeh $+0,10$ harga optimal melinjo $+0,46$ harga optimal petai $\leq$ $1.000 .000,00$

- Bunga bank: alokasi bunga bank di dasarkan pada jumlah tanaman yang ada antara tanaman kopi, cengkeh, melinjo, dan petai, fungsi objektif, yaitu:

28,03 harga optimal kopi $+0,13$ harga optimal cengkeh $+0,06$ harga optimal melinjo $+0,29$ harga optimal petai $\leq$ $633.930,00$

- Biaya tidak terduga: didasarkan pada jumlah tanaman yang ada antara tanaman kopi, cengkeh, melinjo, dan petai, fungsi objektif, yaitu:

37,70 harga optimal kopi $+0,17$ harga optimal cengkeh +0.09 harga optimal melinjo +0.39 harga optimal petai $\leq$ $850.000,00$

- Promosi: alokasi promosi didasarkan pada jumlah produksi yang ada antara tanaman kopi, cengkeh, melinjo, dan petai, fungsi objektif, yaitu:

32,80 harga optimal kopi $+2,23$ harga optimal cengkeh $+2,17$ harga optimal melinjo + 8,31 harga optimal petai $\leq$ Rp.1.000.000,00

- Distribusi: alokasi distribusi di dasarkan pada jumlah produksi yang ada antara tanaman kopi, cengkeh, melinjo, dan petai, fungsi objektif, yaitu:

32,80 harga optimal kopi $+2,23$ harga optimal cengkeh $+2,17$ harga optimal melinjo $+8,31$ harga optimal petai $\leq$ Rp.1.000.000,00

Hasil kendala-kendala dalam penentuan alokasi komponen tiap komoditi dapat dilihat pada Tabel 3.

Nilai optimal sewa tanah sebesar Rp2.981.460,00 terjadi selisih sebesar Rp18.540,00 dari nilai yang diharapkan. Nilai optimal tenaga kerja sebesar Rp3.499.974,00 terjadi selisih sebesar Rp10.878,00 dari nilai yang diharapkan. Nilai optimal pupuk kandang sebesar Rp1.944.430,00 terjadi selisih sebesar Rp55.570,00 dari nilai yang diharapkan. Nilai optimal peralatan sebesar Rp993.820,00 terjadi selisih sebesar Rp6.180,00 dari nilai yang diharapkan. Nilai optimal bunga riil sebesar Rp626.539,00 terjadi selisih sebesar Rp7.391,00 dari nilai yang diharapkan. Nilai optimal biaya tidak terduga sebesar Rp842.586,00 terjadi selisih sebesar Rp7.414,00 dari nilai yang diharapkan. Nilai optimal promosi sebesar Rp1.000.000,00 sama dengan nilai yang diharapkan sehingga tidak terjadi selisih. Nilai optimal distribusi sebesar Rp1.000.000,00 sama dengan nilai yang diharapkan sehingga tidak terjadi selisih.

\section{Analisis Sensistivitas}

Analisis sensitivitas dilakukan untuk mengetahui kepekaan yang dapat mempengaruhi tingkat pendapatan maksimal pada semua komoditi, yaitu: kopi, cengkeh, melinjo, dan petai dalam kendala yang telah ditentukan. Hasil yang diperoleh perbedaan harga optimal dari komoditi kopi, cengkeh, melinjo, dan petai tidak memberikan pengaruh perubahan pada tingkat pendapatan maksimal .Hal ini dapat dilihat pada Tabel 4.

Tabel 4. Sensitivitas Total Pendapatan Terhadap Harga Optimal

\begin{tabular}{lcrrr}
\hline Komoditi & $\begin{array}{l}\text { Harga } \\
\text { optimal } \\
\text { (Rp) }\end{array}$ & $\begin{array}{l}\text { Harga } \\
\text { Riil } \\
\text { (Rp) }\end{array}$ & $\begin{array}{l}\text { Reduced } \\
\text { Gradient } \\
\text { (Rp) }\end{array}$ \\
\hline Kopi & 21.971 & 17.000 & - \\
Cengkeh & 22.102 & 80.000 & - \\
Melinjo & 21.952 & 8.000 & 0 \\
Petai & 21.952 & 25.000 & 0 \\
\hline
\end{tabular}

Sumber: data diolah (2012)

Saat ini harga kopi di tingkat petani bisa mencapai Rp17.000,00 harga cengkeh sebesar Rp80.000,00 harga melinjo sebesar Rp8.000,00 harga petai sebesar Rp25.000,00. Besarnya harga riil komoditi cengkeh dan petai dari harga optimal tidak bisa menutupi rendahnya harga riil dari komoditi kopi dan melinjo hal ini dikarenakan jumlah tanaman cengkeh, melinjo dan petai sangat proposinya sangat kecil dibanding tanaman kopi dengan jumlah tanaman sebanyak $98,30 \%$ yang ada di lahan petani. Sehingga berdasarkan hasil olahan data, proporsi tanaman seperti ini bisa menyebabkan kerugian usaha tani sebesar Rp393.389,00 per tahun dalam satu hektar, 
tetapi usaha tani di lokasi penelitian tetap berjalan tidak mengalami kerugian hal ini disebabkan banyak petani yang melakukan usaha taninya tidak mengeluarkan biaya pada komponen sewa lahan.

Hasil analisis sensitivitas biaya sewa lahan, tenaga kerja, pupuk kandang, peralatan, bunga riil, biaya tidak terduga, promosi, dan distribusi, bahwa Total pendapatan akan terpengaruh oleh pengurangan harga komponen distribusi sebesar Rp13,-. Hal ini dapat dilihat pada Tabel 5.

Tabel 5 Sensitivitas Total Pendapatan Terhadap Kendala-Kendala

\begin{tabular}{llr}
\hline Komponen & $\begin{array}{l}\text { Nilai } \\
\text { akhir } \\
\text { (Rp) }\end{array}$ & $\begin{array}{c}\text { Lagrange } \\
\text { Multiplier } \\
\text { (Rp) }\end{array}$ \\
\hline Sewa lahan & 3.000 .000 & - \\
Tenaga Kerja & 3.500 .000 & - \\
Pupuk Kandang & 2.000 .000 & - \\
Peralatan & 1.000 .000 & - \\
Bunga riil & 633.930 & - \\
Biaya tidak terduga & 850.000 & - \\
Promosi Biaya & 1.000 .000 & - \\
Distribusi Biaya & 1.000 .000 & $(13,00)$ \\
\hline Sumber:data diolah $(2012)$ &
\end{tabular}

Alokasi Biaya Produksi, Promosi, dan Distribusi setiap Komoditi

\section{Kopi}

Total alokasi biaya komponen komoditi kopi sebesar Rp.12.145.413,98 dan tingkat pendapatan untuk komoditi kopi sebesar Rp 9.366.070,00

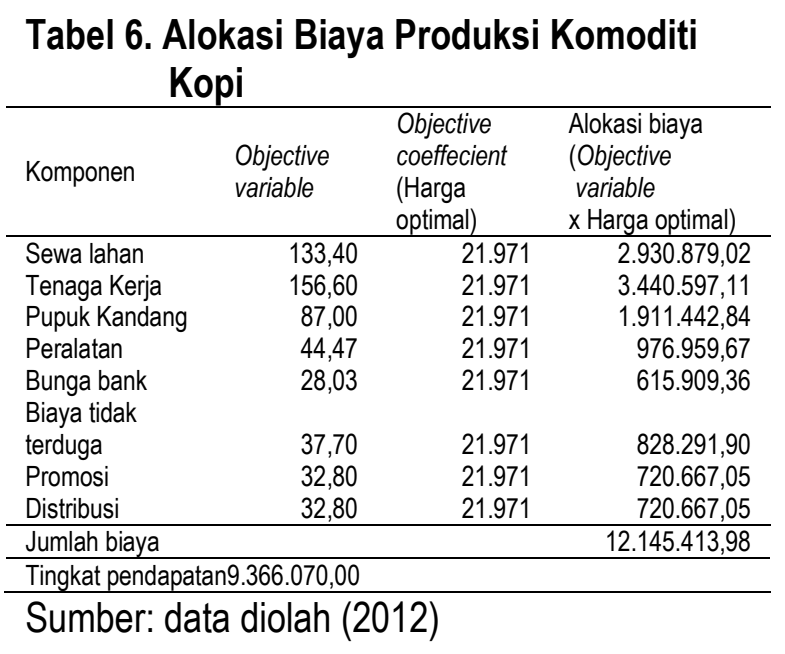

Secara lengkap alokasi biaya produksi untuk tanaman kopi dengan sistem agroforestri di lokasi penelitian dapat dilihat pada Tabel 6 .

\section{Cengkeh}

Total alokasi biaya komponen komoditi cengkeh sebesar Rp148.277,99 dan tingkat pendapatan untuk komoditi kopi sebesar Rp641.830,00. Secara lengkap alokasi biaya produksi untuk tanaman cengkeh dengan sistem agroforestri di lokasi penelitian dapat dilihat pada Tabel 7.

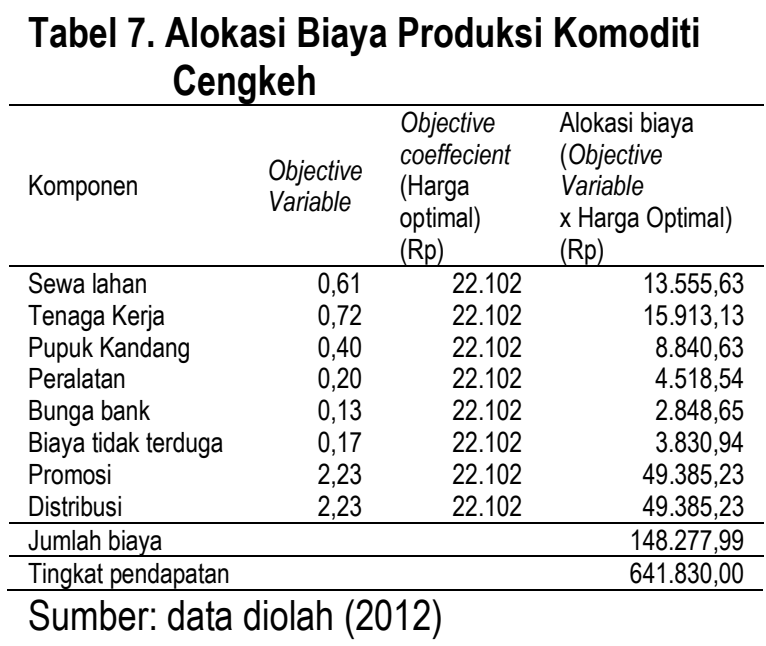

\section{Melinjo}

Total alokasi biaya komponen komoditi melinjo sebesar Rp119.645,71 dan tingkat pendapatan untuk komoditi kopi sebesar Rp617.718,00. Secara lengkap alokasi biaya produksi untuk tanaman melinjo dengan sistem agroforestri di lokasi penelitian dapat dilihat pada Tabel 8.

\section{Tabel 8. Alokasi Biaya Produksi Komoditi} Melinjo

\begin{tabular}{lccr}
\hline Komponen & $\begin{array}{l}\text { Objective } \\
\text { Variable }\end{array}$ & $\begin{array}{l}\text { Objective } \\
\text { coeffesient } \\
\text { (Harga } \\
\text { optimal) (Rp) }\end{array}$ & $\begin{array}{l}\text { Alokasi biaya } \\
\text { (Objective } \\
\text { variable x } \\
\text { Harga optimal) }\end{array}$ \\
\hline Sewa lahan & 0,31 & $21.952,00$ & $6.731,82$ \\
Tenaga Kerja & 0,36 & $21.952,00$ & $7.902,57$ \\
Pupuk Kandang & 0,20 & $21.952,00$ & $4.390,32$ \\
Peralatan & 0,10 & $21.952,00$ & $2.243,94$ \\
Bunga bank & 0,06 & $21.952,00$ & $1.414,66$ \\
biaya tidak terduga & 0,09 & $21.952,00$ & $1.902,47$ \\
Promosi & 2,17 & $21.952,00$ & $47.529,96$ \\
Distribusi & 2,17 & $21.952,00$ & $47.529,96$ \\
\hline Jumlah biaya & & $119.645,71$ \\
\hline Tingkat pendapatan & & $617.718,00$ \\
\hline Sumber: data diolah $(2012)$ &
\end{tabular}




\section{Petai}

Total alokasi biaya komponen komoditi petai sebesar Rp475.471,57 dan tingkat pendapatan untuk komoditi kopi sebesar Rp2.370.772,00. Secara lengkap alokasi biaya produksi untuk tanaman petai dengan sistem agroforestri di lokasi penelitian dapat dilihat pada Tabel 9 .

Tabel 9. Alokasi Biaya Produksi Komoditi Petai

\begin{tabular}{lclr}
\hline Komponen & $\begin{array}{l}\text { Objective } \\
\text { Variable }\end{array}$ & $\begin{array}{l}\text { Coeffecient } \\
\text { (Harga optimal) } \\
\text { (Rp) }\end{array}$ & $\begin{array}{l}\text { Alokasi biaya } \\
\text { (Objective variable } \\
\text { x Harga optimal) } \\
\text { (Rp) }\end{array}$ \\
\hline Sewa lahan & 1,38 & 21.952 & $30.293,20$ \\
Tenaga Kerja & 1,62 & 21.952 & $35.561,59$ \\
Pupuk Kandang & 0,90 & 21.952 & $19.756,44$ \\
Peralatan & 0,46 & 21.952 & $10.097,73$ \\
Bunga bank & 0,29 & 21.952 & $6.365,96$ \\
biaya tidak terduga & 0,39 & 21.952 & $8.561,12$ \\
Promosi & 8,31 & 21.952 & $182.417,76$ \\
Distribusi & 8,31 & 21.952 & $182.417,76$ \\
\hline Jumlah biaya & & & \\
\hline Tingkat pendapatan & & & \\
\hline Sumber: data diolah $(2012)$ & &
\end{tabular}

Perbedaan jumlah alokasi biaya dan tingkat pendapatan sangat besar sekali antara tanaman kopi dengan tanaman cengkeh, melinjo dan petai. Hal ini disebabkan tingkat produksi kopi yang ditanam lebih rendah, tetapi jumlah tanaman di lahan petani hampir mendominasi dari tanaman lain yaitu sebanyak $98,30 \%$.

Produktivitas tanaman kopi di Lampung secara umum rendah, yaitu: sekitar 0,5-0,6 ton, hal ini diduga tanaman kopi di tanam pada daerah-daerah yang miskin hara, tanaman kopi pada daerah yang kesuburan tanahnya baik mampu menghasilkan produktivitas sampai tiga kali lipat, yaitu: sekitar 1,2 ton tiap hektarnya (Hutabarat, 2006).

\section{PEMBAHASAN}

Untuk mengatasi masalah-masalah tersebut sebaiknya petani melakukan penanaman antara tanaman dalam satu lahan dengan proporsi tanaman: kopi sebanyak 170 tanaman $(31,70 \%)$, cengkeh sebanyak 154 tanaman $(28,79 \%)$, melinjo sebanyak 102 tanaman $(19,06 \%)$, petai sebanyak 109 tanaman $(20,37 \%)$. Hasil pengolahan data dengan proporsi tanaman yang hampir sama pada jumlah biaya dan tingkat pendapatan di dasarkan pada harga optimal dapat dilihat pada Tabel 10.
Tabel 10. Jumlah Biaya dan Pendapatan Dengan Jumlah Proporsi Yang Sama

\begin{tabular}{lcrr}
\hline Komoditi & Jumlah biaya & \multicolumn{2}{c}{ Tingkat Pendapatan } \\
\hline Kopi & $\mathrm{Rp} 3.531 .927,51$ & $\mathrm{Rp}$ & $274.196,00$ \\
Cengkeh & $\mathrm{Rp} 3.728 .033,65$ & $\mathrm{Rp}$ & $3.680 .220,00$ \\
Melinjo & $\mathrm{Rp} 2.822 .710,07$ & $\mathrm{Rp}$ & $4.726 .293,00$ \\
Petai & $\mathrm{Rp} 2.900 .778,28$ & $\mathrm{Rp}$ & $4.305 .789,00$ \\
\hline
\end{tabular}

Sumber: data diolah (2012)

Dengan proporsi yang seimbang apabila harga riil di tingkat petani saat ini berlaku dalam setahun dan tingkat produksi tanaman tidak berubah maka berdasarkan hasil pengolahan data, dimungkinkan petani dapat memperoleh keuntungan sebesar Rp122.056.970,00 tiap tahun per hektar.

Proporsi tanaman yang saat ini diterapkan oleh petani di lahan mereka merupakan pengambilan keputusan dengan risiko yang besar, hal ini dikarenakan harga optimal tanaman kopi lebih kecil dari pada harga riil yang ada di tingkat petani saat ini. Hal ini disebabkan semakin kecil harga optimal dibandingkan harga riil maka semakin menguntungkan untuk petani. Harga optimal merupakan harga dimana komoditi tersebut berada pada titik impas harga (BEP harga) dari pendapatan usaha tani. Harga optimal sangat ditentukan oleh proporsi jumlah tanaman yang ada di satu lahan.

Risiko lainnya apabila petani tidak menerapkan proporsi yang sama adalah fluktuasi harga komoditi. Apabila di suatu waktu selanjutnya harga melinjo atau petai meningkat atau harga kopi atau cengkeh rendah, maka jika dilakukan proporsi yang sama pada tanaman diharapkan komoditi petai dan melinjo mampu menahan rendahnya harga kopi dan cengkeh. Manfaat lainnya adalah sistem pemananenan dapat dilakukan secara bergiliran dan terus menerus setiap tahunnya karena musim panen yang berbeda.

Sehingga dalam menghadapi kondisi seperti ini diperlukan suatu pengambilan keputusan bagi petani untuk melakukan penanaman antara kopi, cengkeh, melinjo, dan petai dalam jumlah proporsi yang sama, sehingga diharapkan memberikan keuntungan yang maksimal bagi petani. 


\section{KESIMPULAN DAN SARAN}

Berdasarkan hasil penelitian, maka dapat ditarik beberapa kesimpulan sebagai berikut: (a) Proporsi tanaman di lahan petani yaitu kopi $(98,30 \%)$, cengkeh $(0,45 \%)$, melinjo $(0,23 \%)$, dan petai $(1,02 \%)$ berturut-turut memiliki harga optimal adalah sebesar Rp21.971,00; Rp22.102,00; Rp21.952,00; Rp21.952,00; (b) Proporsi di lahan petani saat ini menimbulkan selisih yang besar yaitu: harga optimal $\geq$ harga riil, yang memiliki risiko dan kerugian yang besar dalam mengelola sistem agroforestri; (c) Apabila proporsi tanaman dalam satu lahan diubah menjadi seimbang dengan proporsi, yaitu: kopi $(31,77 \%)$, cengkeh $(28,79 \%)$, melinjo $(19,06 \%)$, petai $(20,37 \%)$ maka harga optimal komoditi berturut-turut yaitu: Rp.3.292,00; Rp.3.292,00; Rp.3.293,00; Rp.3.292,00.

Disarankan agar petani perlu melakukan proporsi penanaman yang sama pada satu lahan pengelolaan antara tanaman kopi dan kakao untuk memperoleh pendapatan yang lebih maksimal.

\section{DAFTAR REFERENSI}

Bernard T, Wahyu Wiryanta, Paulus Nugrohodjati, dan Novan Frimansyah. 2008. Panduan Lengkap Budidaya \& Bisnis Cabai. Penyunting M. Topan Nixon. PT. Agromedia Pustaka. Jakarta, p:123-126.

Fauzi, Hamdani \& Normela Rachmawati. 2010. Reklamasi Tambang Berbasis Kehutanan Sosial. Studi Kasus di Kabupaten Tapin, Kalimantan Selatan. Prosiding Workshop IPTEK Penyelamatan Hutan Melalui Rehabilitasi Lahan Bekas Tambang Batu Bara. Workshop pada tanggal 20-21 Nopember 2009 di Banjarmasin-Kalimantan Selatan dengan tema "IPTEK Penyelamatan Hutan Melalui Rehabilitasi Lahan Bekas Tambang Batubara". 197-218.

Gunawan. 2010. Pemanfaatan Mikroorganisme Dalam Memperbaiki Lahan Bekas Tambang: Prosfek, Kendala dan Alternatif. Prosiding Workshop IPTEK Penyelamatan Hutan Melalui Rehabilitasi Lahan Bekas Tambang Batu Bara. Workshop pada tanggal 2021 Nopember 2009 di Banjarmasin-
Kalimantan Selatan dengan tema "IPTEK Penyelamatan Hutan Melalui Rehabilitasi Lahan Bekas Tambang Batubara". 53-76.

Hilmanto, Rudi. 2010. Analisis Penelusuran dan Perekaman Teknik Pengelolaan Lahan untuk Standardisasi Kegiatan Produksi Komoditas Agroforestri Lokal. Jurnal Standardisasi. Volume 12, No. 2 Tahun 2010, 69-78.

Hilmanto, Rudi. 2010. Etnoekologi. Lampung: Universitas Lampung.

Hilmanto, Rudi. 2011. Sistem Agroforestri Organik. Penerbit: Lembaga Penelitian Universitas Lampung.p:140-150

Hilmanto, Rudi dan Subekti Rahayu. 2011. Opini: Strategi Usaha Tani menghadapi Fluktuasi Harga. Kiprah Agroforestri. Volume 4, No. 3, Desember 2011, p: 13-15.

Hutabarat, Budiman. 2006. Analisis SalingPengaruh Harga Kopi Indonesia dan Dunia. Jurnal Agro Ekonomi, Volume 24 No.1, Mei 2006, 21-40.

Thinkalytics, Patralekha Bhattacharya. 2008. Marketing Mix Modeling: Techniques and Challenges. Sesug Proceedings. Paper ST-152, 1-6.

Purwanto, S. Andy Cahyono, dan Sunaryo. 2003. Bauran Pemasaran pada Kegiatan Rekreasi Hutan di Batu Raden, Jawa Tengah. Jurnal Info Sosial dan Ekonomi Kehutanan. Volume 9, No. 4. Desember 2009.

Sadic, Senay. 2010. Determining The Weights of Marketing Mix Components Using Analytic Network Process. Istanbul: Industrial Engineering Department Istanbul Technical University Istanbul.

Trison, Soni. 2008. Konsep dan Proses Pemasaran Produk Agroforestri dalam Pemasaran Produk - Produk Agroforestri, 3-1 s.d.3-14.

Wijatnika. 2009. Inisiatif Pengelolaan Hutan Lestari dan Berkelanjutan Oleh Kelompok Pendukung SHK di Lampung. Lampung: WALHI. 